herbaria; but the oval scars of the caudex and the chaffy scales of the rachis, às they appear in living specimens, must entitle it to be regarded as a distinct species.

\title{
Description of a New Species of Apseudes.
} [Plate VI.]

By William A. Haswell, M.A., B.Sc.

Apseudes obtusifrons.

Head as long as the two following segments, crossed by oblique grooves in the form of an $\mathrm{X}$; rostrum short, rounded. Pleon as long as the four last segments of the pereion, ciliate at the sides, the last segment short, its apex bifid. Upper antennæ with the peduncle very stout, first segment nearly as long as the head, second segment about a third of the length of the first, third segment small; flagellum shorter than the peduncle, with nine segments; secondary flagellum with six segments. Outer antennæ rather longer than the peduncle of the inner; basal and second joints of the peduncle thicker than the rest, each with a small ovate, ciliated process; third and fourth joints very small, fifth greatly elongated; flagellum with six segments. Mandibles with the palp short, uniarticulate. Maxillipedes richly ciliated internally. First pair of legs with the propodos oval, produced below into a finger which has two low tubercles at its base; both carpus and propodos thickly clothed with long slender hairs. Second pair of thoracic limbs expanded and foliaceous; carpus with two short stout spines on its outer border; propodos with four longer spines on its outer border and another internal to the insertion of the dactylos; dactylos taking the form of an ovate plate, closely fringed terminally with fine hairs. Third and fourth pairs of thoracic appendages similar, with the propodos rather short, the dactylos long and very slender; fifth and sixth pairs with the propodos longer, armed with straight setæ; dactylos 
very small, penicillate; last pair smaller than the rest. Inner flagellum of caudal appendage with 17 joints ; outer very short, two jointed. Length $\frac{3}{8}$ ths inch.

Hab. Port Jackson (dredged on a sandy bottom).

\section{Explanation of Plate VI.}

Fig. 1. Apseudes obtusifrons $\times 8$.

,, 2. Upper antennæ $\times 22$.

, 3. Lower antennæ $\times 22$.

, 4. First pair of thoracic limbs $\times 22$.

, 5. Second pair $\times 22$.

,, 5'. Extremity of the same $\times 44$.

, 6. Third pair of thoracic limbs $\times 22$.

, 7. Fifth pair $\times 22$.

,, 8. Caudal appendages $\times 44$.

NUTES AND EXHIBITS.

The Honble. William Macleay exhibited a large specimen (about six iuches in diameter) of Mylitta australis a fungus of the Truffle family, generally known under the name of "Native bread." He stated that the specimen had been dug up on the Blue Mountains by the Honble. James Norton, and he expressed a doubt as to its edible qualities, notwithstanding the name given to it.

WEDNESDAY, OCTOBER 26тн, 1881.

The President, J. C. Cox, M.D., F.L.S., \&c., in the Chair.

\section{MEMBERS ELECTED.}

Messrs. James Conway, Alexander Morton, Paul Fittel, Fredk. Williams, and the Honble. J. Malbon Thomson. 


\section{$2 \mathrm{BHL}$ Biodiversity Heritage Library}

Haswell, W A. 1882. "Description of a new species of Apseudes." Proceedings of the Linnean Society of New South Wales 6, 748-749. https://doi.org/10.5962/bhl.part.11896.

View This Item Online: https://www.biodiversitylibrary.org/item/22895

DOI: https://doi.org/10.5962/bhl.part.11896

Permalink: https://www.biodiversitylibrary.org/partpdf/11896

\section{Holding Institution}

MBLWHOI Library

\section{Sponsored by}

MBLWHOI Library

\section{Copyright \& Reuse}

Copyright Status: NOT_IN_COPYRIGHT

This document was created from content at the Biodiversity Heritage Library, the world's largest open access digital library for biodiversity literature and archives. Visit BHL at https://www.biodiversitylibrary.org. 